\begin{tabular}{|c|c|c|c|}
\hline \multirow{2}{*}{$\begin{array}{c}\text { LARUS } \\
\text { Hrvatska akademija } \\
\text { znanosti i umjetnosti }\end{array}$} & 55 & $26-33$ str. & Zagreb 2020. \\
\cline { 2 - 4 } & $(2020)$ & 3 slike & \multicolumn{3}{|c|}{$\begin{array}{c}\text { Primljeno 18.5.2020. } \\
\text { Prihvaćeno od Razreda za prirodne znanosti HAZU 28.11.2020. }\end{array}$} \\
\hline
\end{tabular}

UDK 598.296.1+591.543.43

\title{
CLIMATE CHANGE AND THE SPRING MIGRATION OF THE EUROPEAN SERIN Serinus serinus
}

\section{Klimatske promjene i proljetne migracije žutarice Serinus serinus}

\section{Zdravko Dolenec}

\author{
Mokrice 132, 49243 Oroslavlje, Croatia
}

\begin{abstract}
Numerous migratory bird species have advanced their spring arrival over the past few decades. These arriving changes may be associated with climate change. The aim of this paper was to examine how the timing of the European Serin Serinus serinus spring migration is related to the year and the local spring air temperatures. The study was conducted in the rural area of the village Mokrice in north-western Croatia. This study shows that the European Serins have significantly advanced their first arrival date over the 37-year period by eight days. Over the same research period, the mean spring air temperature has significantly increased as well. The results indicate that the average spring air temperature affects the spring migration phenology of the European Serin in north-western Croatia.
\end{abstract}

Keywords: climate change, European Serin, arrival date, NW Croatia

\section{INTRODUCTION}

Earth climate is changing (IPPC 2014), and evidence of the effect of the recent climate warming on plants and animals has rapidly accumulated. For instance, studies from across the world have illustrated that the flowering phenology has advanced in the spring and that this is closely linked with temperature changes (e.g. GaIRA et al. 2014). Furthermore, spring warming is linked with the earlier

e-mail: zdravko.dolenec@biol.pmf.hr 
first spring flight by insects (e.g. Kharouba et al. 2014). In birds, climate change affects reproductive success (e.g. Vengerov 2017), geographical distribution (e.g. Lehikoinen \& VirkKala 2016), clutch initiation (e.g. Dolenec 2019a, 2019b), etc. Birds are one of the most studied groups of vertebrates, and most papers look at their phenology phenomena. Numerous studies show evidence of the advancement in the bird migration phenology. For instance, the arrival date of the Barn Swallow Hirundo rustica populations in Poland has advanced by 18 days over the period from 1970 - 2009 (BIAdun et al. 2011). Furthermore, arrival dates of the European Stonechat Saxicola rubicola have advanced by 21 days (1980 - 2016) in the mixed farmland area in north-western Croatia (Dolenec 2018a). These shifts in migration phenology are associated with high spring air temperatures. Furthermore, there are reports from other continents on the shift in the bird spring migration as a response to climate change (e.g. BeAumont et al. 2006). The aim of this paper was to examine how the timing of the spring migration of the European Serin (Serinus serinus) related to the year and the local mean spring air temperatures in the period $1980-2016$. The European Serin is a common, small and short-migratory bird in north-western Croatia. According to GILL \& WRIGHT (2006), this bird species belongs to the family of Finches (Fringillidae) and the order of passerine (Passeriformes).

\section{MATERIAL AND METHODS}

The area of this study is rural area located in the Mokrice village $\left(46^{\circ} 00^{\prime} \mathrm{N}-\right.$ $15^{\circ} 55^{\prime} \mathrm{E}, 6.4 \mathrm{~km}^{2}$, altitude approximately $140 \mathrm{~m}$, Northwest Croatia). The data were collected between 1980 and 2016. This area mostly consists of mixed landscape (orchards, meadows, hedges, gardens etc.), with a small mixed deciduous forest (dominated by the Hornbeam Carpinus betulus and the Pediculate Oak Quercus robur). Observations between 1980 and 2016 were recorded by the author of this paper. The spring migration phenology for each year was calculated as the average of the first five bird arrivals registered for that year, according to Вотн et al. (2005). Dates were converted to numerical values in the following manner: $1=1^{\text {st }}$ March. I have used temperature records for the study period from the nearest weather station $(20 \mathrm{~km})$ at the Maksimir station (Meteorological Office in Zagreb). The average mean spring air temperature was obtained from the average temperature for March and April (the arrival period). Temperature is an important parameter of weather in many long-term studies of bird phenology (e.g. Tøtтrup et al. 2010, Dolenec 2018b). The statistical analysis of the trends in migration phenology and the spring average air temperatures was calculated by regression analysis and Pearson's coefficient of correlation. Significance was set at $\mathrm{p} \leq 0.05$ in all cases. Statistical analyses were performed using the SPSS 13.0 statistical package for Windows. 


\section{RESULTS AND DISCUSSION}

An analysis of long-term observations of the spring temperatures at the Maksimir meteorological station has revealed statistically significant trends of increase in the March-April mean air temperatures in the period between 1980 and 2016 (mean $=9.2^{\circ} \mathrm{C} \pm 1.36$, range $=6.5^{\circ} \mathrm{C}(1987)$ to $11.9^{\circ} \mathrm{C}(2012)$; linear regression: slope $=+0.07, \mathrm{r}^{2}=0.29, \mathrm{p}<0.001, \mathrm{n}=37$; Figure 1$)$. In the research period, the spring warmed by 2.6 degrees Celsius. In the years between 1980 and 2016, the earliest spring migration of the European Serin was recorded on $22^{\text {nd }}$ March (2006), whilst the latest was recorded on $15^{\text {th }}$ April (1984). The mean arrival date was $31^{\text {st }}$ March $\pm 5.6(1980-2016)$. The difference between the minimum and the maximum values was 24 days. The relationship between the date of arrival and the year was statistically significant (linear regression: slope $=-0.22, \mathrm{r}^{2}=0.18, \mathrm{p}=$ $0.008, \mathrm{n}=37$; Figure 2). The arrival date of the European Serin advanced by up to eight days in the period 1980 - 2016. The relationship between the mean spring air temperature and the arrival was also significant (linear regression: slope = 1.97, $\mathrm{r}^{2}=0.23, \mathrm{p}=0.003, \mathrm{n}=37$; Figure 3). Consequently, this results show that relatively high mean spring air temperatures can be associated with earlier arrival in the breeding grounds.

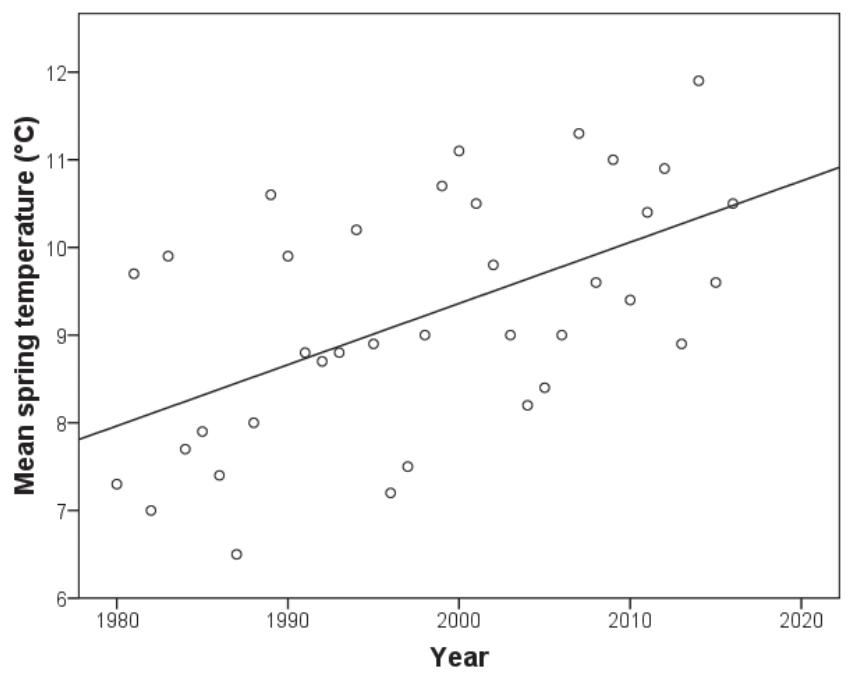

Figure 1. Relationship between the mean spring air temperature (March-April) and the year in the study area $1980-2016$ (slope $=+0.07, \mathrm{r}^{2}=0.29, \mathrm{p}<0.001, \mathrm{n}=37$ ).

Slika 1. Odnos između srednje proljetne temperature (ožujak-travanj) i godina istraživanja u razdoblju od 1980. do 2016. godine (nagib $=+0,07, r^{2}=0,29, p<0,001, n=37$ ). 


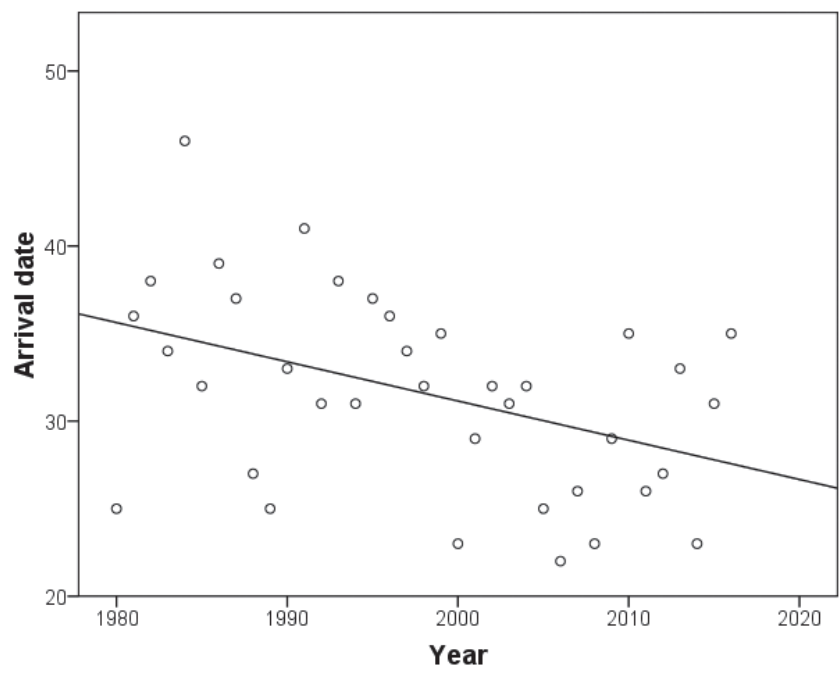

Figure 2. Relationship between the arrival date and the year in the study area $1980-2016$ $\left(1=1^{\text {st }}\right.$ March; slope $\left.=-0.22, \mathrm{r}^{2}=0.18, \mathrm{p}=0.008 . \mathrm{n}=37\right)$.

Slika 2. Odnos između datuma povratka i godina istraživanja u razdoblju od 1980. do 2016. godine ( 1 = 1 ožujak; nagib $\left.=-0,22, r^{2}=0,18, p=0,008 . n=37\right)$.

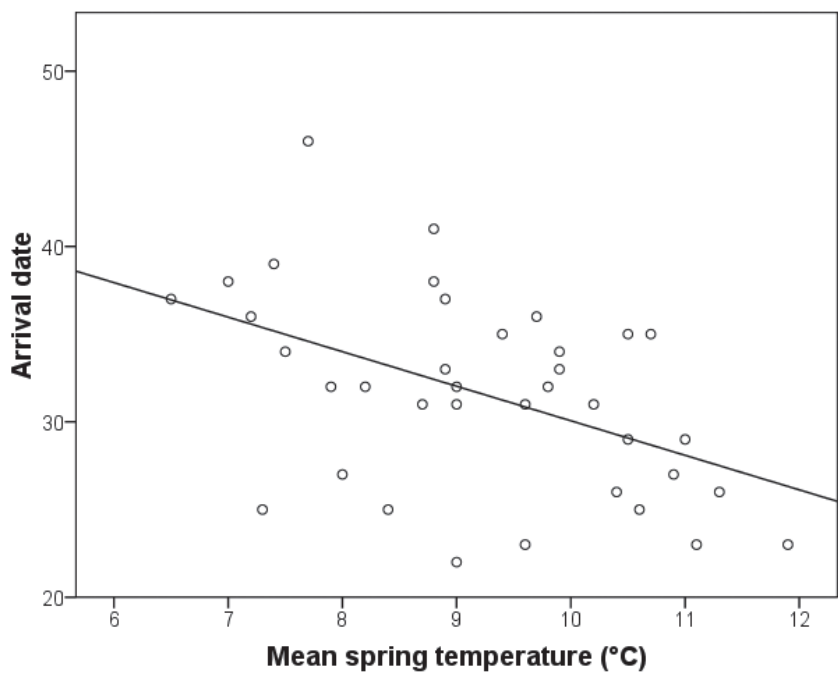

Figure 3. Relationship between the arrival date and the mean spring air temperature (MarchApril) and the year in the study area $1980-2016\left(1=1^{\text {st }}\right.$ March; slope $=-1.97, \mathrm{r}^{2}=0.23$, $\mathrm{p}=0.003, \mathrm{n}=37$ ).

Slika 3. Odnos između datuma povratka i srednje proljetne temperature (ožujak-travanj) u razdoblju od 1980. do 2016. godine ( $1=1$ ožujak; nagib $=-1.97, r^{2}=0,23, p=0,003, n$ $=37$ ). 
The impact of the recent global warming has already been detected in numerous plant and animal species, including birds. I have examined the first arrival dates of the European Serin over a 37-year period, and their correlation with the local spring air temperatures and the research year. The European Serin has advanced its first arrival date between 1980 and 2016 by eight days in north-western Croatia. This advance was negative in correlation with the spring warmings. My results indicate that the average spring air temperature affects the spring migration phenology of the European Serin. Thus, the earliest arrival dates in this work can be associated with temperature changes. Previous studies showed different results: for instance, TrYJANOwsKi et al. (2002) documented an advance in the European Serin's spring arrival, whereas BIADUN et al. (2009) found no significant trend in this respect. This inter-population heterogeneity probably stems from different selection pressures in the environment, i.e. different phenotypic plastic in different populations. In general, the first (or mean) arrival date of many, but not all, bird species and populations has advanced across the globe: for instance, in the USA (Zelt et al. 2017), Lithuania (Zalakevicius et al. 2006), and Australia (Sмітн \& Sмiтн 2012). Furthermore, birds breeding in Croatia have shown a trend towards an earlier arrival - both short- and long-distance migratory species (e.g. Dolenec 2013, 2017), but not all (e.g. Dolenec 2012, 2018c). The advancement in the arrival is related to the local mean spring air temperatures in Croatia.

Finally, numerous species and populations have shown major changes in many ecosystems in response to rapid climate warming over the past 40 years. Climate change has emerged as one of the most important topics in ecology and provides new challenges and opportunities for research (Primack \& MillerRushing 2012). According to Tøтtrup et al. (2010), „understanding what cues migratory organisms use to arrive at an optimum time is important for increasing our knowledge of fundamental issues like decision making in organisms during migration and is crucial for future protection of migratory organisms". 


\section{References}

Beaumont, L. J., Mcallan J. A. W., Hughe, L. (2006): A matter of timing: changes in the first date of arrival and last date of departure of Australian migratory birds. Global Change Biology 12: 1339-1354.

Biadun, W., Kitowski, I., Filipiuk, E. (2009): Trends in the arrival dates of spring migrants in Lublin (E Poland). Acta Ornithologica 44: 89-94.

Biadun, W., Kitowski, I., Filipiuk, E. (2011): Study on the First Arrival Date of Spring Avian Migrants to Eastern Poland. Polish Journal of Environmental Study 20: 843-849.

Вотн, C., Bijasma, R. G., Visser, M. E. (2005): Climatic effects on timing of spring migration and breeding in a long-distance migrant, the pied flycatcher Ficedula hypoleuca. Journal of Avian Biology 36: 368-373.

Dolenec, Z. (2012): Non-significant trends towards earlier or later arrival date of the Pied Wagtail (Motacilla alba L.) in NW Croatia. Polish Journal of Ecology 60: 581-584.

Dolenec, Z. (2013): Implications of temperature change on spring arrival dates of chiffchaff (Phylloscopus collibyta Vieillot) in a site in Croatia. Current Science 104: 700-702.

Dolenec, Z. (2017): Advances in arrival date of the Common Cuckoo (Cuculus canorus L.) in the forest of northwestern Croatia. Šumarski list 14: 571-576. (In Croatian with English summary)

Dolenec, Z. (2018a): Role of temperature during spring migration of the European Stonechat, Saxicola rubicola (Linaeus, 1766) (Aves: Muscicapidae) in NW Croatia. Acta Zoologica Bulgarica 70: 523-526.

Dolenec, Z. (2018b): Results of long-term monitoring of timing of laying in deciduous forest Blue Tit (Cyanistes caeruleus L.) in northwestern Croatia. Šumarski list 142: 381386. (In Croatian with English summary)

Dolenec, Z. (2018c): Comparison of arrival dates of the long-distance migratory Redbacked Shrike Lanius collurio with spring air temperatures and year. Larus 20: 33-40.

Dolenec, Z. (2019a): Temporal shift in timing of breeding of European starling (Sturnus vulgaris Linnaeus) population. Current Science 116: 29-30.

Dolenec, Z. (2019b): Interannual variation of clutch initiation of the great tit (Parus major Linnaeus) in relation to the local air temperature. Current Science 117: 924-926.

IPCC 2014. Climate change 2014: impacts, adaptation, and vulnerability. Part B: regional aspects. Contribution of working group II to the fifth assessment report of the Intergovernmental Panel on Climate Change [Barros, V.R., Field, C.B., Dokken, D.J., Mastrandrea, M.D., Mach, K.J., Bilir, T.E., Chatterjee, M., Ebi, K.L., Estrada, Y.O., Genova, R.C., Girma, B., Kissel, E.S., Levy, A.N., MacCracken, S., Mastrandrea, P.R., White, L.L. (eds.)]. Cambridge University Press, Cambridge, United Kingdom and New York, NY, 688 pp.

Gaira, K. S., Rawal, R. S., Rawat, B., Bhatt, L. D. (2014): Impact of climate change on the flowering of Rhododendron arboreum in central Himalaya, India. Current Science 102: 1735-1738.

Gill, F., Wright, M. (2006): Birds of the world. Princeton University Press, New Jersey. 
Kharouba, H. M., Paquette, S. R., Kerr, J. T., Vellend, M. (2014): Predicting the sensitivity of butterfly phenology to temperature over the past century. Global Change Biology 20: 504-514.

Lehikoinen, A., VirkKala, R. (2016): North by north-west: climate change and directions of density shifts in birds. Global Change Biology 22: 1121-1129.

Primack, R. B., Miller-Rushing, A. J. (2012): Uncovering, Collecting, and Analyzing Records to Investigate the Ecological Impacts of Climate Change: A Template from Thoreau's Concord. BioScience 62: 170-181.

Sмiтh, P., Sмiтh, J. (2012): Climate change and bird migration in south-eastern Australia. Emu 112: 333-342.

Tøttrup, A. P., Raino, K., Coppack, T., Lahikoinen, E., Rahbek, C., Thorup, K. (2010): Local Temperature Fine-Turnes the Timing of Spring Migration in Birds. Integrative and Comparative Biology 50: 293-304.

Tryjanowski, P., Kuzniak, S., Sparks, T. (2002): Earlier arrival of some farmland migrants in western Poland. Ibis 144: 62-68.

Vengerov, P. D. (2017): Effect of Rise in Spring Air Temperature on the Arrival Dates and Reproductive Success of the Song Thrush, Turdus philomelos (C.L. Brehm, 1831) in the Forest-Steppe of the Russian Plain. Russian Journal of Ecology 48: 178-184.

Zalakevicius, M., Bartkeviciene, G., Roudonikis, L., Janulaitis, J. (2006): Spring arrival response to climate change in birds: a case study from eastern Europe. Journal of Ornithology 147: 326-343.

Zelt, J., Deleon, R. L., Arab, A., Laurent, K., Snodgrass, J. W. (2017): Long-term trends in avian migration timing fort the state of New York. Wilson Journal of Ornithology 129: 271-282. 


\section{SAŽETAK}

Ptice su jedna od najbolje istraženih životinjskih skupina u odnosu na recentne klimatske promjene, a to se posebice odnosi na njihovu fenologiju. Mnoge vrste ptica reagiraju na sve toplija proljeća posljednjih desetljeća te se vraćaju ranije sa zimovanja ili sve ranije polažu jaja, ali ne sve vrste ili populacije unutar iste vrste. U ovom članku prezentirani su rezultati praćenja proljetne selidbe lokalne populacije žutarice Serinus serinus na području naselja Mokrice $\left(46^{\circ} 00^{\prime} \mathrm{N}-15^{\circ} 55^{\prime} \mathrm{E} ; 6,4 \mathrm{~km}^{2}\right.$; oko $140 \mathrm{~m}$ nadmorske visine; sjeverozapadna Hrvatska) u razdoblju od 1980. do 2016. godine. Prvo proljetno opažanje ptice često se koristi u analizama. Međutim u ovome članku, prvo pojavljivanje predstavlja prosjek prvih pet opaženih ptica kako bi se izbjegao mogući utjecaj eventualno ekstremno ranog povratka jednog primjerka na ukupni rezultat. Rezultati ukazuju na sve raniji povratak žutarice sa zimovanja na područje gniježđenja, odnosno, ptice se vraćaju osam dana ranije 2016. u odnosu na 1980. godinu. U spomenutom razdoblju došlo je do statistički značajnog porasta srednje proljetne temperature zraka, a korelacija između datuma povratka i srednje temperature ukazuje na značajnu povezanost tih parametara što u konačnici upućuje na zaključak da sve toplija proljetna temperatura utječe na raniji povratak žutarice sa zimovanja u 37-godišnjem razdoblju. 